Article

\title{
Recycling of Cigarette Butts in Fired Clay Bricks: A New Laboratory Investigation
}

\author{
Halenur Kurmus * and Abbas Mohajerani ${ }^{D}$ \\ School of Engineering, RMIT University, Melbourne 3000, Australia; abbas.mohajerani@rmit.edu.au \\ * Correspondence: halenur.kurmus@student.rmit.edu.au
}

Received: 10 January 2020; Accepted: 7 February 2020; Published: 9 February 2020

check for updates

\begin{abstract}
Cigarette butts (CBs) are the most commonly littered waste material in the world. It is estimated that over 5.7 trillion cigarettes are consumed worldwide each year. Consequently, millions of tonnes of highly toxic waste are contaminating the environment. CBs are composed of cellulose acetate filters - a polymer with poor biodegradability—and which, depending upon the environmental conditions, can take many years to decompose. In this study, fired clay bricks were manufactured with $0.5 \%, 1 \%, 1.5 \%$, and $2 \%$ CBs by mass and tested against control bricks with $0 \%$ CBs. The results revealed a decrease in compressive strength from $48.6 \mathrm{MPa}$ for $0 \% \mathrm{CB}$ content bricks to $30.8 \mathrm{MPa}$ for $1 \% \mathrm{CB}$ content bricks, and a decrease in dry density with the increase in CB content, from $2114 \mathrm{~kg} / \mathrm{m}^{3}$ for the control bricks to $1983 \mathrm{~kg} / \mathrm{m}^{3}$ and $1969 \mathrm{~kg} / \mathrm{m}^{3}$ for $1 \%$ and $2 \%$ CB content bricks. The highest value of water absorption appeared for $2 \% \mathrm{CB}$ content bricks, which reached an absorption rate of $13.1 \%$ compared to $9 \%$ for the control bricks. The energy required during the firing process was calculated with a saving of up to $10.20 \%$, for bricks incorporating $1 \%$ CBs. The thermal conductivity of the samples showed a reduction of $17 \%$ from 1.078 to $0.898 \mathrm{~W} \mathrm{~m}^{-1} \cdot \mathrm{K}^{-1}$ with the addition of $1 \%$ CBs. In addition, the manufactured bricks were tested for efflorescence, an initial rate of absorption (IRA), microstructural analysis, and shrinkage. A life-cycle assessment (LCA) is recommended to analyze the environmental impacts of bricks incorporating CBs.
\end{abstract}

Keywords: recycling; cigarette butts; fired clay bricks; energy saving; brick manufacturing

\section{Introduction}

Due to the increasing requirements of environmentally-friendly, lightweight, and low-cost construction materials, many studies have been devoted to finding ways to optimize the performance of the materials used in the building industry, such that the effect on the environment is minimized $[1,2]$. Ultimately, one-third of the world's energy consumption is consumed in buildings [3], while 50\% of this is lost due to the poor thermal conductivity of the walls [4]. Fired clay bricks are the most conventionally used masonry material around the globe [5]. Their interesting physical, thermal, and mechanical properties allow them to be the ultimate material for the construction of buildings, especially their durability, compactness, and strength [6].

Buildings consume great amounts of thermal energy. During the winter, the internal warmth generated by heating is lost due to the high thermal conductivity of traditional bricks, while, in the summer, the coolness can escape due to the same reasoning. Therefore, it is essential to develop a method to produce thermally-resistant walls, while remaining in the realms of practicality and maintaining the aesthetic appeal of the construction. Hence, enhancing the insulation effectiveness of construction material will significantly lower the impact on the environment.

Many studies have been conducted to find ways to improve the thermal conductivity of fired clay bricks, with one being the recycling of waste materials composed of high organic content. It was found that the greater the energy consumption during the firing process, the greater the thermal conductivity 
of the bricks $[7,8]$. Therefore, the incorporation of additive materials with high organic content may create voids within the structure during the firing process and reduce energy consumption [9]. Wastes have higher heating values (HHV), which are added through self-combustion within the clay mixture, and, hence, less energy is required during the firing process [10]. In doing so, the porosity will increase due to the creation of pores, and the thermal conductivity and density of the fired clay bricks will decrease [11,12]. However, these modifications to the microstructure and composition of the brick will have a negative impact on the mechanical resistance of the material.

The correlation between density and thermal conductivity is evident [9]. However, it is conceivable to discover situations where there is a variation between thermal conductivity and density $[7,13]$. The sources of these variations may be the nature and distribution of the pores or the presence of certain mineralogical components [13,14]. A study was completed on 29 samples of clay bricks in which the thermal conductivity was determined. Furthermore, the relationship with their physical, microstructural, and compositional features was evaluated. It was found that mineralogical components, like Ca-rich silicates, quartz, and amorphous phase, play a significant role in decreasing the insulation properties of fired clay bricks, while open pores have a positive effect on thermal conductivity [13].

A number of studies have been conducted on recycling wastes in fired clay bricks to investigate the relationship between the use of additives in fired clay bricks and the micro-pores and nano-pores formed as a result. Such additives include waste sawdust [15], desulfurization slag and basic oxygen furnace aggregates [16], marble powder [17], biomass incineration [18], recycled paper processing residues [4], bio-briquette ash [19], sugarcane bagasse ash [20], and cigarette butts [21-27]. A recent study revealed the substructures produced by the additive olive pomace ( $10 \%$ weight) that resulted in a $14.4 \%$ decrease in thermal conductivity [28]. Comparing this to expanded vermiculite (10\% content), a pore-forming material that expands when heated declined from 0.96 to $0.65 \mathrm{~W} / \mathrm{mK}$, which is a $32 \%$ drop in thermal conductivity [3]. While olive mill solid residue (OMSD) demonstrated the highest decrease in thermal conductivity of 70\% with the use of 15\% OMSD in fired clay bricks [29].

\section{Cigarette Butts}

Cigarette butts (CBs) are the most commonly littered waste material in the world. The Tobacco Atlas [30] reported that 5.7 trillion cigarettes were consumed worldwide in the year 2016 and that about $97 \%$ of the cigarette filters were made up of cellulose acetate filters, which is a modified natural polymer [31]. In Australia, every year, more than 20 billion cigarettes are consumed, and 7 billion are littered into the environment (Figure 1) [32]. Clean Up Australia [33] reported that CBs were the most common source of rubbish collected under the miscellaneous category, which represented $91.5 \%$.

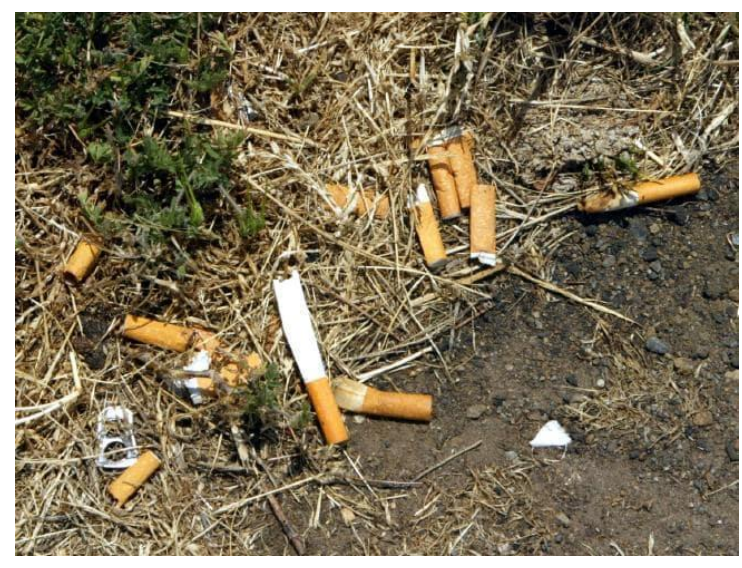

Figure 1. Littered CBs. 
When CBs are littered, harmful chemicals are leached into the environment, which poseleading concerns for the global environment and the quality of urban and aquatic life. In cigarette smoke, it is possible to classify more than 4000 chemical components that are generated during burning or that are distilled from tobacco, of which 69 are carcinogenic [34,35]. Cigarettes generally incorporate cellulose acetate filters, which are designed to fully or partially retain particulate smoke components, including tar and toxic chemicals [36]. Cellulose acetate filters have poor biodegradability and can take up to 18 months to decompose under normal environmental conditions, and, hence, pose a severe dilemma in terms of toxic waste and litter disposal [37,38]. CBs littered on streets are commonly washed away into stormwater drains and end up on beaches, or in rivers and harbors where they leach toxic chemicals [39].

Landfilling and incineration are possible disposal methods for CBs. However, both methods are costly and universally unsustainable. The incineration of CBs can result in the emission of various hazardous substances, and landfilling of $\mathrm{CBs}$ will continue to be an environmental hazard regardless of the location of the landfill and can be severely detrimental to the environment and human health $[40,41]$. Therefore, it is becoming vital to find a practical and effective way to recycle CB waste. An alternative to the growing pollution catastrophe may be the method of recycling CBs into composite building materials such as fired clay bricks.

Mohajerani et al. [27] propose that all CBs can be sustainably recycled in fired clay bricks by incorporating $1 \% \mathrm{CBs}$ in $2.5 \%$ of the world's brick production. The study involves incorporating various percentages of CBs in clay bricks, including 2.5\%, $5 \%, 7.5 \%$, and $10 \%[23,24,27]$. Experiments have confirmed a steady decrease in dry density and compressive strength with an increase in the $\mathrm{CB}$ content of the clay bricks. This decrease in density increases the porosity, which results in an exponential drop in thermal conductivity. Thus, this results in improved thermal performance and greater energy efficiency [26]. The lower energy consumption during the firing process is contributed through the high calorific value of the CBs. CBs have higher heating values (HHV), which are added through self-combustion within the clay mixture, and, hence, less energy is required during the firing process [10]. Moreover, the high temperatures during the firing stage will result in the volatilization of dangerous components and eliminate any toxic compounds [27].

This paper is the continuation of an ongoing study on the incorporation of CBs in fired bricks. In this study, the properties of $0.5 \%, 1 \%, 1.5 \%$, and $2 \%$ CB bricks by mass (equivalent to approximately $10 \mathrm{~kg} / \mathrm{m}^{3}, 20 \mathrm{~kg} / \mathrm{m}^{3}, 30 \mathrm{~kg} / \mathrm{m}^{3}$, and $40 \mathrm{~kg} / \mathrm{m}^{3} \mathrm{CBs}$ ) were investigated and compared with controlled fired clay bricks $\left(0 \mathrm{~kg} / \mathrm{m}^{3} \mathrm{CBs}\right)$. The energy saving percentage during the firing process of bricks and the reduction in thermal conductivity are presented as a function of the CBs present in the mixtures. Additionally, numerous tests were carried out, including water absorption, compressive strength, efflorescence, an initial rate of absorption (IRA), density, shrinkage, and microstructural analysis.

\section{Materials and Methods}

\subsection{Materials}

The soil used in preparing the fired clay bricks was sandy silty clay (MC), which was provided by PHG Bricks Victoria (Victoria, Australia). Geotechnical laboratory tests were conducted on the soil, including the particle size distribution test (PSD), liquid limit, and plastic limit, according to the Australian Standards [42-44].

CBs of varying sizes and brands were provided by Buttout Australia Pty Ltd. (Melbourne, Australia), which were collected from dry receptacles. On arrival, the CBs were dried and sanitized at $105^{\circ}$ for $24 \mathrm{~h}$ in the oven (Figure 2), and then stored in airtight plastic bags.

Chemical and mineral analyses were conducted to determine the major chemical and mineral constituents of the experimental soil using X-ray fluorescence (XRF) (S4 Pioneer, Bruker, Billerica, MA, USA) and an X-ray diffraction analyzer (XRD) (D8 Endeavor, Bruker, Billerica, MA, USA). 
Thermo-gravimetric analysis (TGA) was carried out using the Perkin-Elmer TGA 8000 instrument (Waltham, MA, USA) to investigate the weight loss of the $0 \%$ and $1 \%$ CB content clay mixtures.

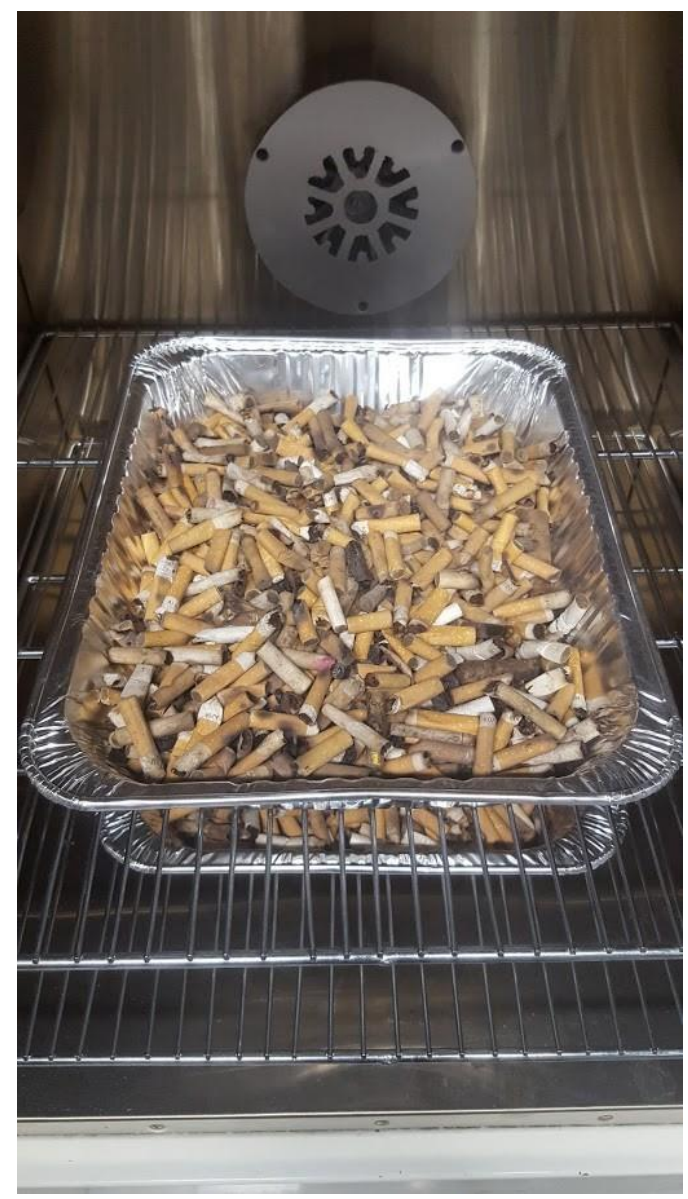

Figure 2. CBs used in this study.

The geotechnical properties of the soil used in this study were determined according to the Australian Standards $[43,44]$. By testing the Atterberg limits, it was found that the liquid limit for the brick soil was $34 \%$, while the plastic limit was $25 \%$, respectively. These values are the average results from three replicate tests.

The particle size distribution for the soil sample was determined through sieve analysis and is shown in Figure 3. The brick soil comprised $77.5 \%$ fine particles $(<75 \mu \mathrm{m})$. According to these results, the Unified soil classification of the brick soils is sandy silty clay (MC) [42].

Chemical analyses were conducted to obtain the chemical composition of the brick soil using XRF. As shown in Table 1, the main compound found in the soil was silicon dioxide, which is followed by aluminium oxide and ferric oxide. XRD was utilized to identify the main crystalline phases on a $<75-\mu \mathrm{m}$ sample of the brick soil (Figure 4). The brick soil displayed Quartz $\left(\mathrm{SiO}_{2}\right)$ as the primary crystalline phase while Muscovite $\left(\mathrm{KAI}_{2}\left(\mathrm{AISi}_{3} \mathrm{O}_{10}\right)(\mathrm{F}, \mathrm{OH})_{2}\right)$, Clinochlore $\left(\mathrm{Mg}_{5} \mathrm{AI}\left(\mathrm{AlSi}_{3} \mathrm{O}_{10}\right)(\mathrm{OH})_{8}\right)$, Mikasaite $\left(\mathrm{Fe}_{2}\left(\mathrm{SO}_{4}\right)_{3}\right)$, and Albite $\left(\mathrm{Na}\left(\mathrm{AlSi}_{3} \mathrm{O}_{8}\right)\right.$ presented a lower intensity. 


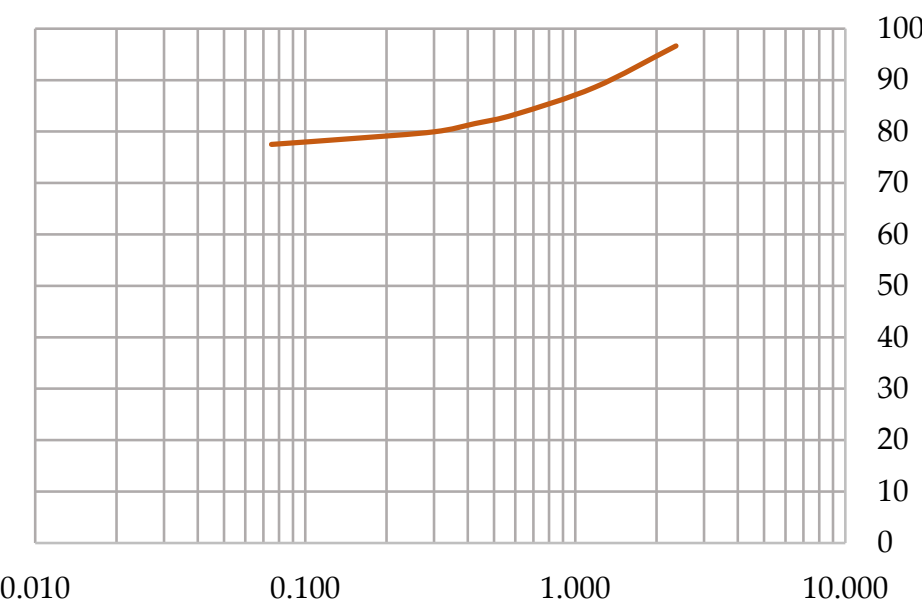

Particle Diameter (mm)

Figure 3. Particle-size distribution curve of brick soil used in this study.

Table 1. Soil chemical properties.

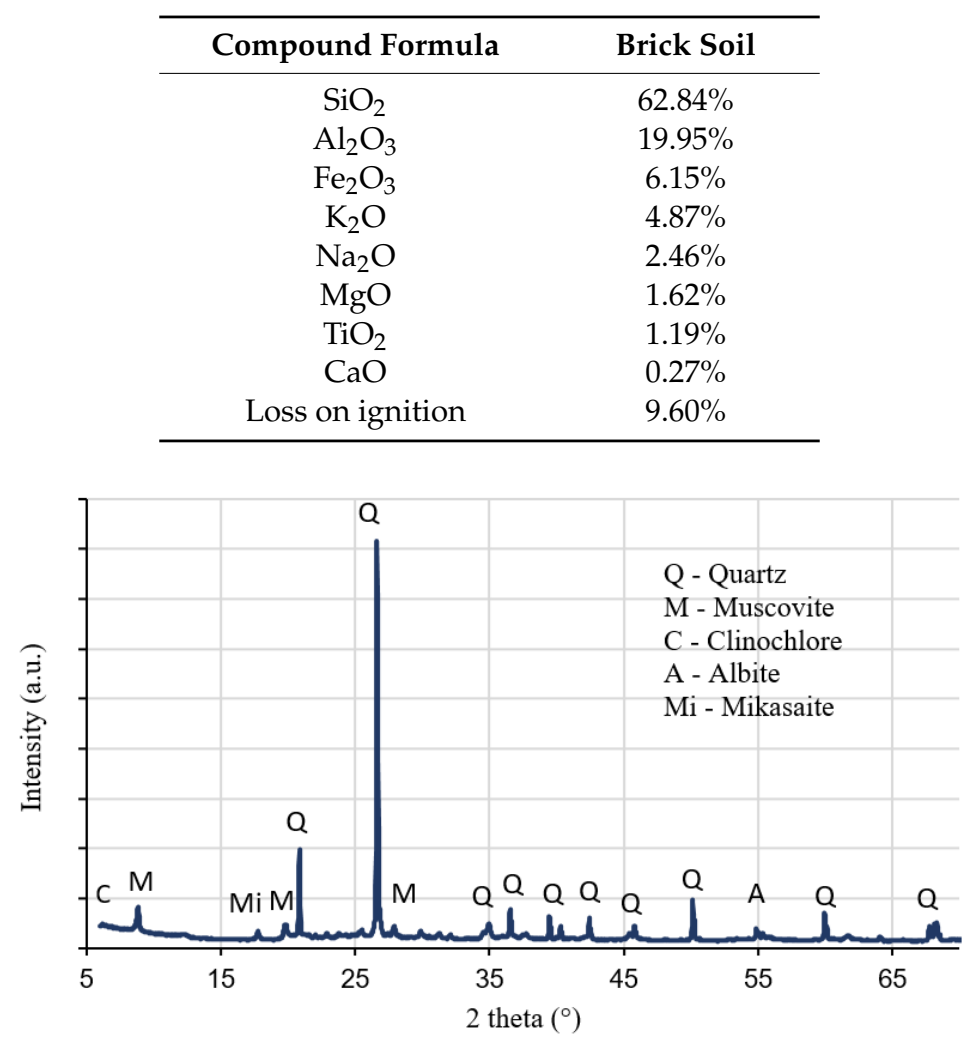

Figure 4. XRD patterns of brick soil.

TGA was performed to monitor and compare the weight loss of the $0 \%$ and $1 \%$ CB content clay mixtures while the samples were exposed to a constant rate of heat. The samples were heated from $30{ }^{\circ} \mathrm{C}$ to $850{ }^{\circ} \mathrm{C}$ at $20^{\circ} \mathrm{C} / \mathrm{min}$ in an air atmosphere with a purge rate of $15 \mathrm{~mL} / \mathrm{min}$. Figure 5 presents the thermogravimetric (TG) and differential thermal (DT) curves for $0 \%$ and $1 \%$ CB content clay mixtures, respectively. The $0 \%$ and $1 \% \mathrm{CB}$ content clay mixtures demonstrated mass loss characteristics of $6.1 \%$ ( $0 \%$ CB content clay mixture) and $7.3 \%$ ( $1 \%$ CB content clay mixture). The initial decrease occurred at $150{ }^{\circ} \mathrm{C}$. This is due to the evaporation of water within the mixture. While a majority of the mass loss occurred at $150-400{ }^{\circ} \mathrm{C}$ and $500-600^{\circ} \mathrm{C}$, during these ranges, organic matter is burned and water 
molecules of the chemical compounds are released. The final mass loss occurred between $600-800{ }^{\circ} \mathrm{C}$. This can be related to the decomposition of carbonates and sulphides. The $1.2 \%$ difference in mass loss between the two samples could be due to the high volatile organic content present in the $1 \% \mathrm{CB}$ content clay mixture that burnt off during the high temperatures.

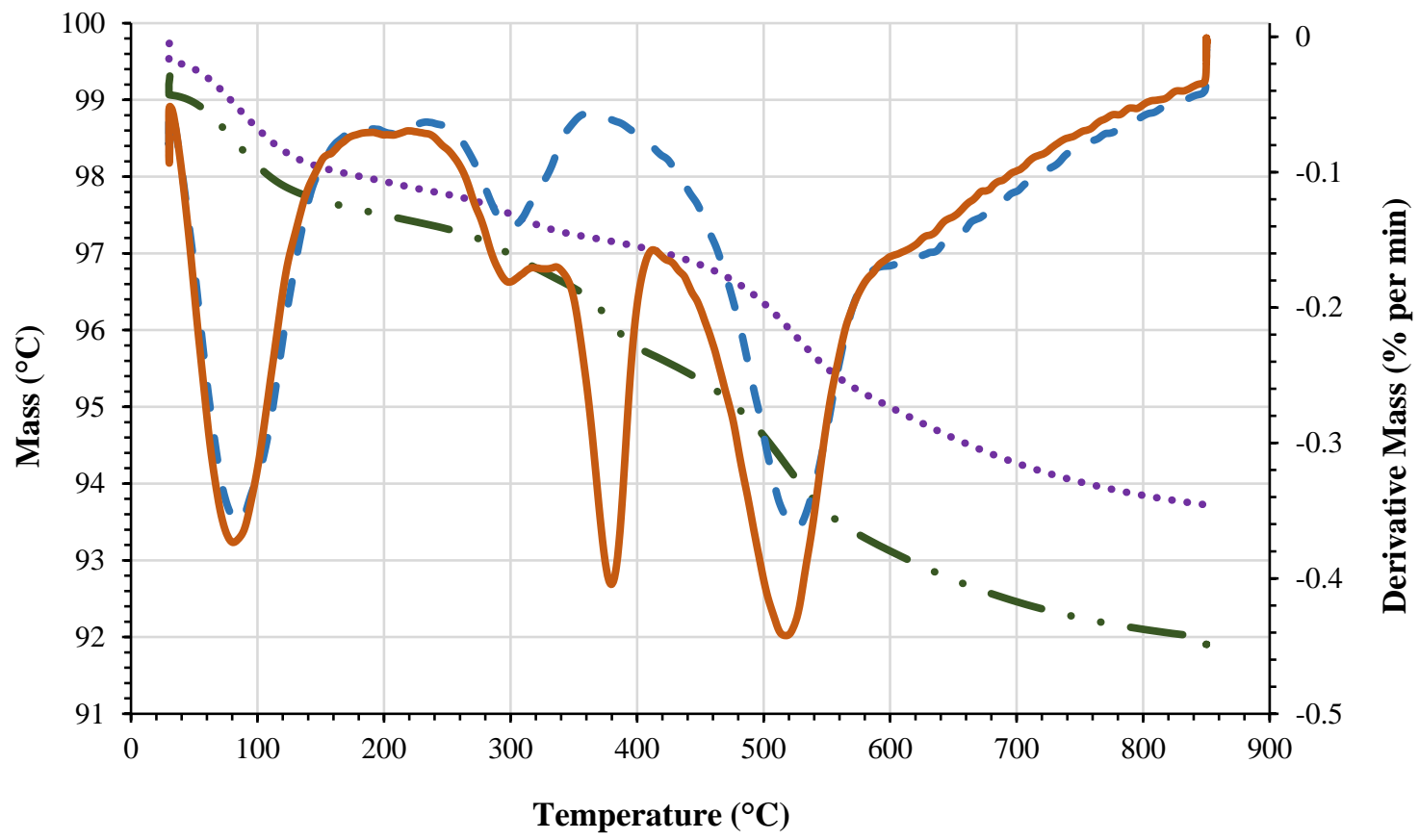

$$
\begin{aligned}
\ldots . . . \text { TG } 0 \% \text { CB Clay Mixture }- & \text { TG } 1 \% \text { TG Clay Mixture } \\
- & \text { DT } 0 \% \text { CB Clay Mixture DT } 1 \% \text { CB Clay Mixture }
\end{aligned}
$$

Figure 5. TG and DTA curves of $0 \% \mathrm{CB}$ content clay mixture and $1 \% \mathrm{CB}$ content clay mixture.

\subsection{Brick Sample Preparation}

The bricks were prepared incorporating varying percentages of cigarette butts and a control sample with $0 \%$ CBs to investigate the mechanical and physical properties of the bricks. The mixes were categorized by the percentage of $\mathrm{CBs}$ by the mass of the brick. $\mathrm{CB}(0.0)$ was the control sample and consisted of no CBs. CB (0.5) consisted of $0.5 \%$ CBs by mass. CB (1.0) consisted of $1 \%$ CBs by mass, CB (1.5) consisted of $1.5 \%$ CBs by mass, and CB (2.0) consisted of $2 \%$ CBs by mass.

The soil and CB mixtures were prepared using a Hobart mechanical mixer for a duration of 25 min with a $15.5 \%$ water content. Then it was placed in airtight plastic bags for $48 \mathrm{~h}$ to uniformly distribute the moisture throughout the mix. The mixtures were then compacted in molds of a 100-mm diameter to yield bricks with heights of approximately $50 \mathrm{~mm}$ with a compaction pressure of $240 \mathrm{kpa}$. The specimens were air dried for $24 \mathrm{~h}$ before being placed in an oven for $24 \mathrm{~h}$ at $105^{\circ} \mathrm{C}$. Once removed from the oven, the samples were then fired in an electric furnace at $1050{ }^{\circ} \mathrm{C}$ for $3 \mathrm{~h}$. During each stage of the preparation process, the height, diameter, and weight of the samples were measured using an electric scale and digital caliper. The fired samples were tested for water absorption, compressive strength, efflorescence, initial rate of absorption (IRA), density, shrinkage, thermal conductivity, microstructural analysis, and energy savings, according to the Australian Standards [45] (Figure 6). All the results presented are the average of three replicates. 


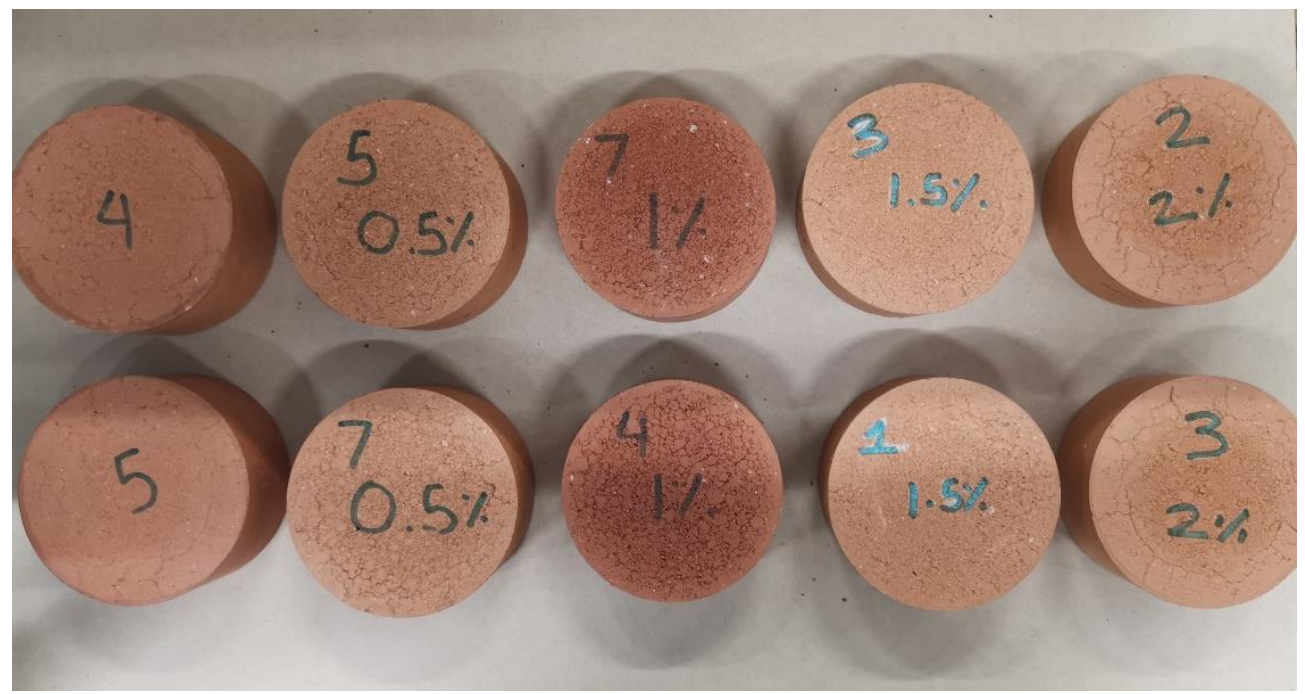

Figure 6. Some of the samples prepared in this study.

\subsection{Energy Saving}

The calorific value of a material determines the amount of heat (energy) that is produced by the complete combustion of that material. Therefore, utilizing a material with a high calorific value as a partial replacement material in a mixture with a low calorific value will result in a reduction in the overall required energy for bricks, since additional energy is produced by the constituents of the material when combusted, as compared to a standard mixture.

In the calculation method [27], the firing energy for the fired clay bricks incorporating CBs was calculated, assuming that $2 \mathrm{MJ} \cdot \mathrm{kg}^{-1}$ energy was used for firing the bricks. This value was based on a survey conducted in 1993-1994, which shows that the firing energy consumption is in a range of 2 to $3 \mathrm{MJ} \cdot \mathrm{kg}^{-3}$ in Association of Southeast Asian Nations (ASEAN) countries [46]. A laboratory experiment was conducted to determine the calorific value of the CBs. Samples of used CBs were tested, and the calorific value for the CBs was found to be $16.53 \mathrm{MJ} / \mathrm{kg}$.

The calculations were conducted for the CB bricks by considering the weight of CBs incorporated as well as the calorific value of the cellulose acetate. Therefore, the estimated firing energy saved through the addition of CBs into bricks and compared to the control brick was calculated as follows.

$$
\begin{gathered}
\text { Energy Used for Control Clay Brick }(\mathrm{MJ}) \mathrm{Q}_{1}=\mathrm{q} \times \mathrm{m}_{1} \\
\text { Energy Used for Clay-B Brick }(\mathrm{MJ}) \quad \mathrm{Q}_{2}=\mathrm{q} \times \mathrm{m}_{2}-\mathrm{CV} \times \mathrm{m}_{3} \\
\text { Energy Saved }(\mathrm{MJ}) \mathrm{Q}_{1}-\mathrm{Q}_{2}=\left(\mathrm{q} \times \mathrm{m}_{1}\right)-\left(\mathrm{q} \times \mathrm{m}_{2}-\mathrm{CV} \times \mathrm{m}_{3}\right) \\
\text { Energy Saved }(\%) \Delta E(\%)=\frac{Q_{1}-Q_{2}}{Q_{1}} \times 100 \%=\frac{\left(\mathrm{q} \times \mathrm{m}_{1}\right)-\left(\mathrm{q} \times \mathrm{m}_{2}-\mathrm{CV} \times \mathrm{m}_{3}\right)}{\mathrm{q} \times \mathrm{m}_{1}} \times 100 \%
\end{gathered}
$$

where:

$\mathrm{q}=$ energy used for brick firing $=2 \mathrm{MJ} / \mathrm{kg}$;

$\mathrm{m}_{1}=$ mass of clay in control clay brick $(\mathrm{kg}) ;$

$\mathrm{m}_{2}=$ mass of clay in clay-CB brick $(\mathrm{kg}) ;$

$\mathrm{m}_{3}=$ mass of CBs in clay-CB brick (kg);

$\mathrm{CV}=$ calorific value of cellulose acetate $=16.53 \mathrm{MJ} / \mathrm{kg}$. 


\subsection{Thermal Conductivity}

Due to the increasing requirements for energy savings, the thermal insulation properties of building materials, such as bricks, have become significant. The heat loss from a building depends on the thermal conductivity of the materials in the roof and wall. While the thermal conductivity of a brick is the quantity of heat transmitted through the brick. Components that influence the effective thermal conductivity of bricks are generally the geometrical design [47], microstructure, and mineralogical composition [48].

As part of these studies, Kadir and Mohajerani [22] developed Equation (5) to estimate the thermal conductivity of brick samples. The thermal conductivity of 256 results of various types of concrete, aggregate, and bricks was obtained to develop an equation using regression analysis as a function of density. Whereby, it was found that K (thermal conductivity) can be represented using its relationship with Dry Density.

$$
\mathrm{k}=0.0559 \mathrm{e}^{(0.0014)(\mathrm{Dd} 1)}
$$

Utilizing Equations (6)-(8), Equation (9) was developed to estimate the energy transfer of the fired clay brick samples. According to Fourier's Law, we find that the Heat Flow Rate (W) can be expressed as:

$$
\mathrm{q}=\mathrm{k} \times \mathrm{A} \times \frac{\Delta \mathrm{T}}{\mathrm{L}}
$$

Since the Heat flow rate is measured in Watts, we can also determine that, through reconfiguring, the Current Intensity formula can be found, which is shown below.

$$
\mathrm{q}=\frac{\mathrm{Q}}{\Delta \mathrm{T}}
$$

Hence,

$$
\frac{\mathrm{Q}}{\mathrm{t}}=\mathrm{k} \times \mathrm{A} \times \frac{\Delta \mathrm{T}}{\mathrm{L}}
$$

Re-arranging the above equations, we see a new formula for energy transfer.

$$
Q=\frac{\mathrm{k} \cdot A \cdot \Delta T}{L} \times t
$$

where:

$\mathrm{q}$ = heat flow rate $(\mathrm{W})$;

$\Delta \mathrm{T}=\mathrm{T}_{\text {hot }}-\mathrm{T}_{\text {cold }}=$ change in temperature (Kelvin);

$\mathrm{Q}=$ energy transfer $(\mathrm{Wh})$;

$\mathrm{t}=$ time (h);

$\mathrm{k}=$ thermal conductivity $(\mathrm{W} / \mathrm{mK})$;

$\mathrm{L}=$ thickness of the brick;

$\mathrm{A}=$ surface area of the material transferring heat.

\section{Results and Discussion}

\subsection{Properties of the Fired Clay Bricks}

Property tests were conducted for five types of the sample: $0 \%$ CBs, $0.5 \%, 1 \%, 1.5 \%$, and $2 \% ! C B s$. The results can be seen in Figures 7-12. The dry density of the prepared bricks decreased from $2114 \mathrm{~kg} / \mathrm{m}^{3}$ for controlled bricks to $1983 \mathrm{~kg} / \mathrm{m}^{3}$ for bricks with $1 \%$ CBs by mass. The addition of CBs resulted in the bricks becoming more porous. The development of pores within the structure of the brick can be associated with the added CBs that burnt off during the firing process as a consequence of the volatile organic content in the CBs. 


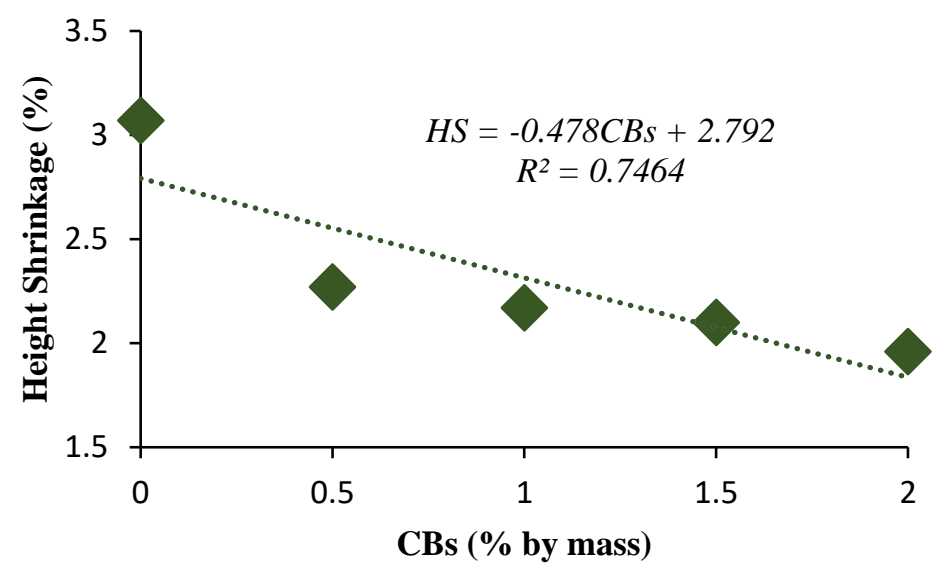

Figure 7. Height shrinkage versus CB percentage by mass.

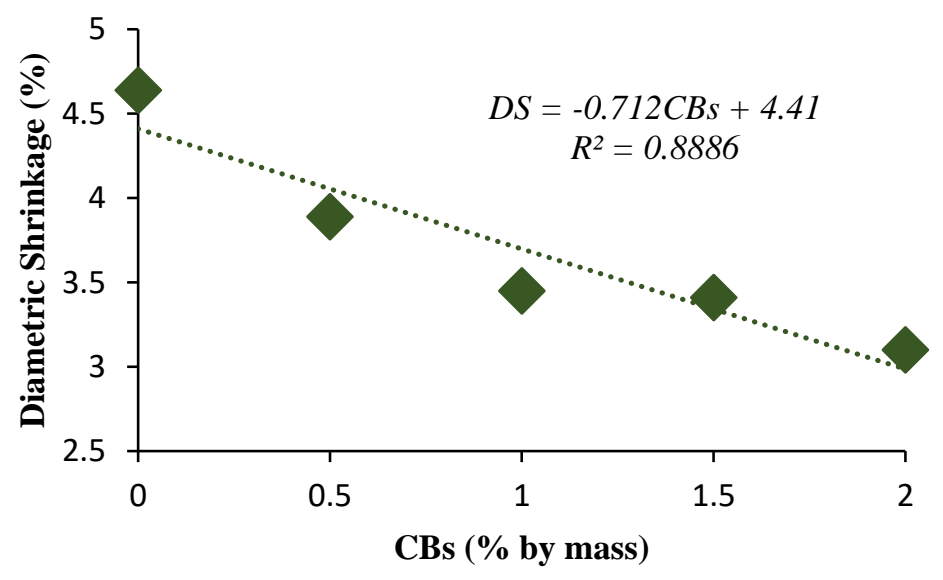

Figure 8. Diametric shrinkage versus CB percentage by mass.

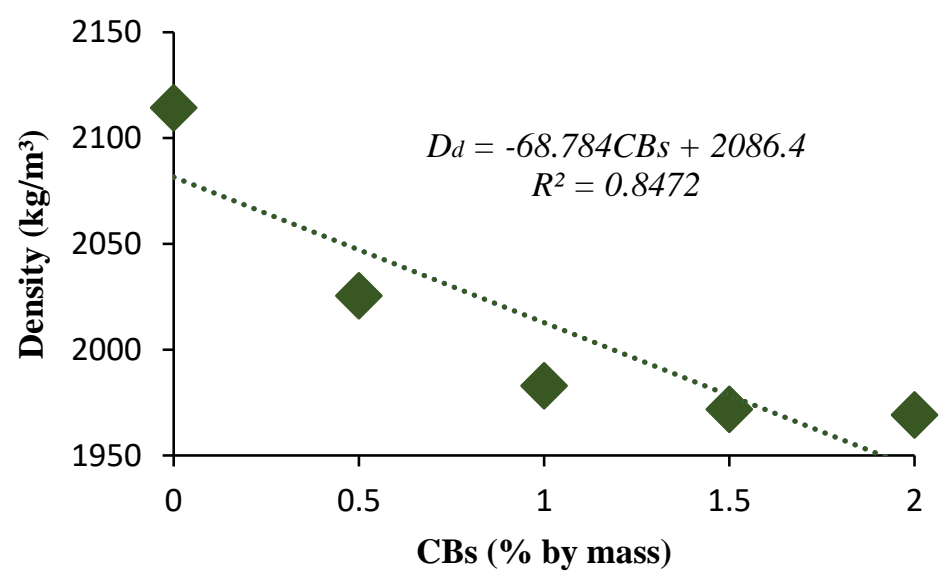

Figure 9. Dry density versus CB percentage by mass. 


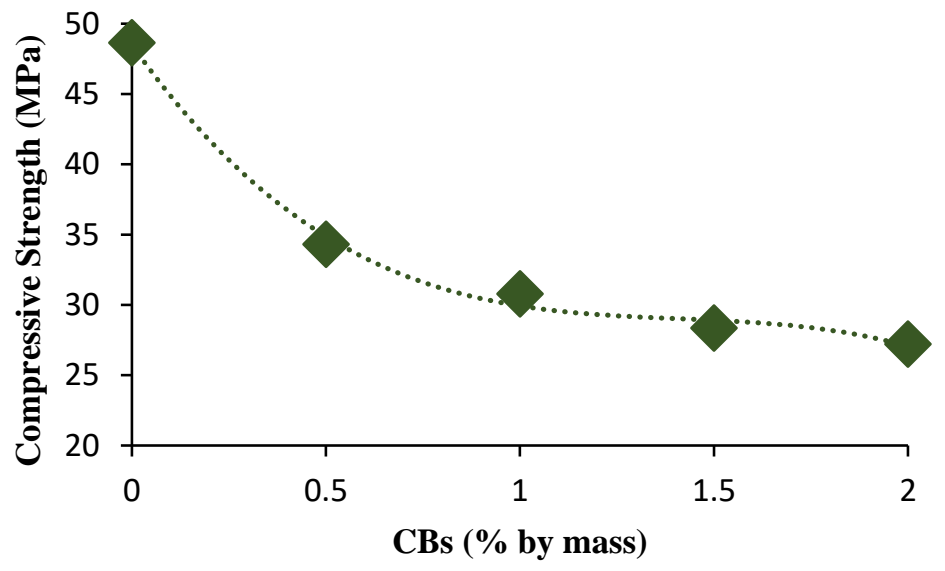

Figure 10. Compressive strength versus $C B$ percentage by mass.

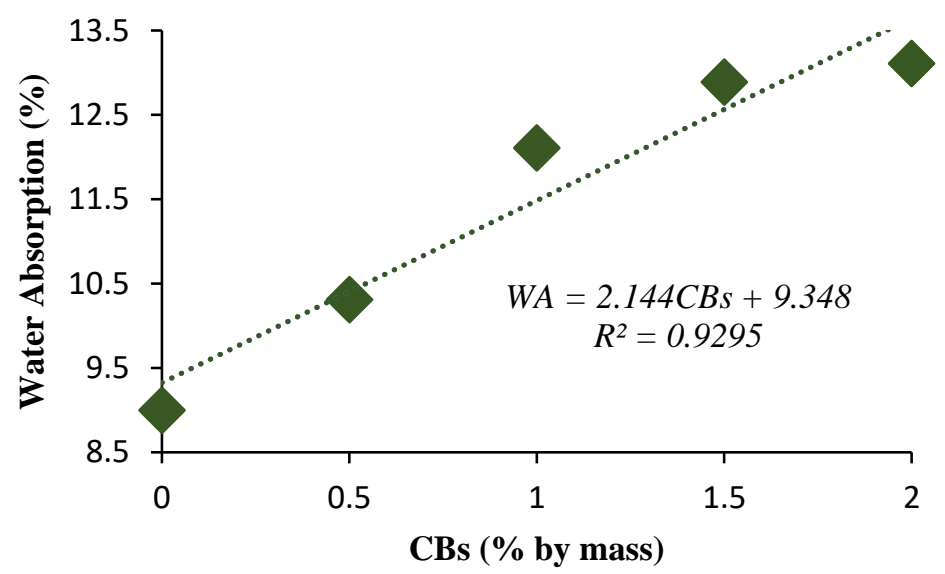

Figure 11. Water absorption versus $C B$ percentage by mass.

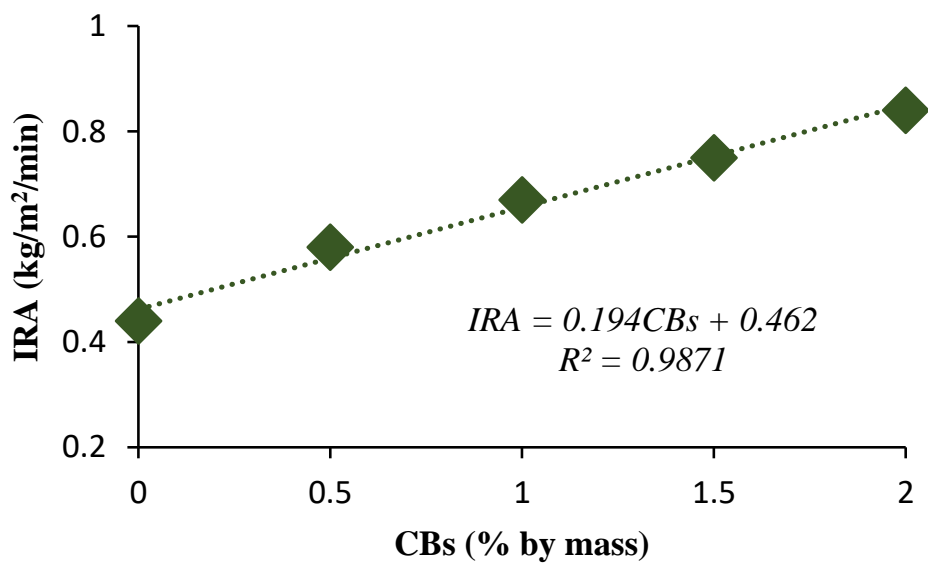

Figure 12. IRA versus $C B$ percentage by mass.

The compressive strength of the bricks tested decreased from $48.6 \mathrm{MPa}$ for $0 \% \mathrm{CB}$ content to $30.8 \mathrm{MPa}$ for $1 \% \mathrm{CB}$ content, and 27.2 MPa for $2 \% \mathrm{CB}$ content. The minimum recommended compressive strength is 3-5 MPa, and 5-10 MPa for non-load and load-bearing fired clay bricks, respectively [49-51]. The reduction in strength was associated with the loss of organic content in the CBs, which were exposed to firing in the furnace. This resulted in the formation of bigger pores due to the CBs that burnt off, which lowered the strength of the CB-amended fired clay bricks. Similar results have been 
observed with the incorporation of hemp shiv fibers in fly ash-based alkaline mortars. The addition of hemp fibers led to a reduction in compressive strength due to the increase in porosity [52].

The higher percentage of $\mathrm{CB}$ content resulted in an increase in water absorption and IRA. The water absorption was measured at $12.1 \%$ for $1 \%$ CBs by mass compared to $9 \%$ for $0 \%$ CBs by mass (Figure 13 ). The greatest value of water absorption was measured at $13.1 \%$ for $2 \%$ CBs by mass. The IRA was found to be $0.67 \mathrm{~kg} \cdot \mathrm{m}^{-2} \cdot \mathrm{min}^{-1}$ for $1 \%$ CBs by mass and $0.44 \mathrm{~kg} \mathrm{~m}^{-2} \cdot \mathrm{min}^{-1}$ for $0 \%$ CBs by mass, which falls within the IRA range of 0.2 and $5 \mathrm{~kg} \cdot \mathrm{m}^{-2} \cdot \mathrm{min}^{-1}$ [53]. A similar trend was observed with the incorporation of biosolids in fired clay bricks. The increase in the percentage of biosolids resulted in an increase in IRA due to the creation of pores during the firing process [54]. Water absorption and IRA values signify the long-term durability performance of the bricks. Therefore, excessively high values can lead to cracking as a consequence of volume changes.

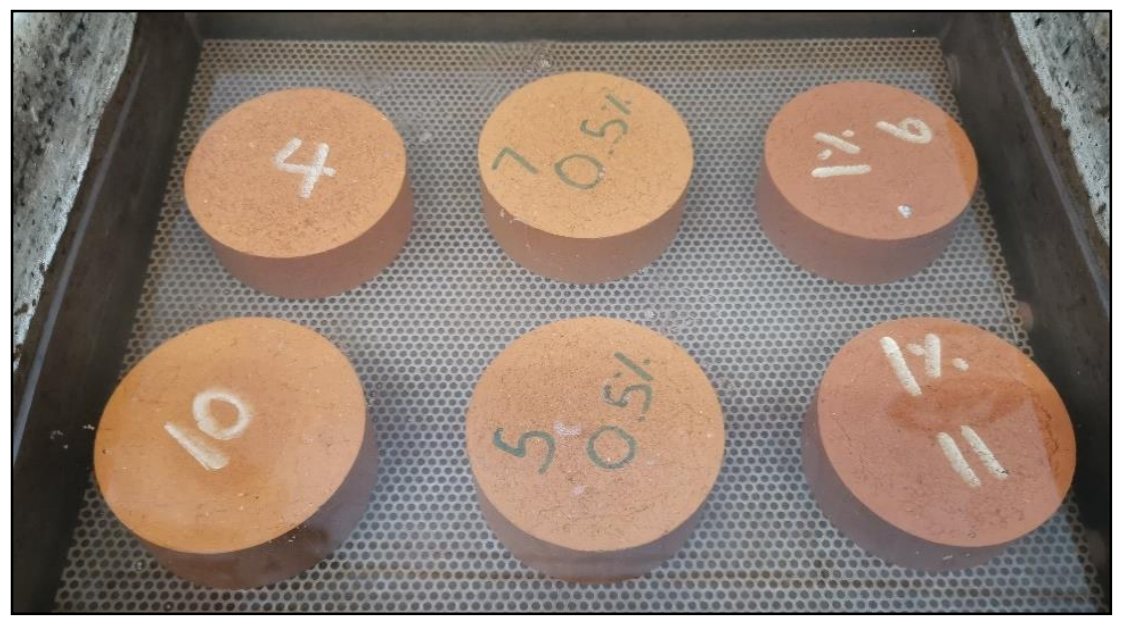

Figure 13. 24-hour cold water and 5-hour boiling water test.

Drying and firing shrinkage are essential indicators for evaluating the suitability of the added CBs from a durability point of view. The bricks are exposed to high temperatures in the furnace. Therefore, any cracks that occur during drying can result in brick failure during firing. The results revealed a decreasing trend in height and diametric shrinkage with the increase in $\mathrm{CB}$ content. The diametric shrinkage values obtained were $4.64 \%, 3.45 \%$, and $3.1 \%$ for $0 \%, 1 \%$, and $2 \%$ CBs by mass bricks, respectively. The decreasing trend may be the consequence of the volatile content present in the $\mathrm{CBs}$ that burnt off, which results in a change in size. A similar trend in the variation of shrinkage in fired clay bricks with the increase in waste glass has been reported by Phonphuak et al. [55].

Analysis of efflorescence was carried out for the clay bricks and the clay-CB bricks. Efflorescence is the formation of salt deposits on or near the surface of the brick that causes a change in appearance [56]. For comparison purposes, 10 samples were prepared and sorted into two pairs so that both specimens of each pair had the same appearance. All external faces of each pair of specimens were examined (Figure 14). The results for the potential efflorescence of the control, $0.5 \%$, and $1.5 \%$ CB bricks displayed "Nil" observable efflorescence, while there was "Slight" efflorescence for $1 \%$, and "Moderate" efflorescence for the $2 \%$ CB bricks, according to the Australian Standards [57].

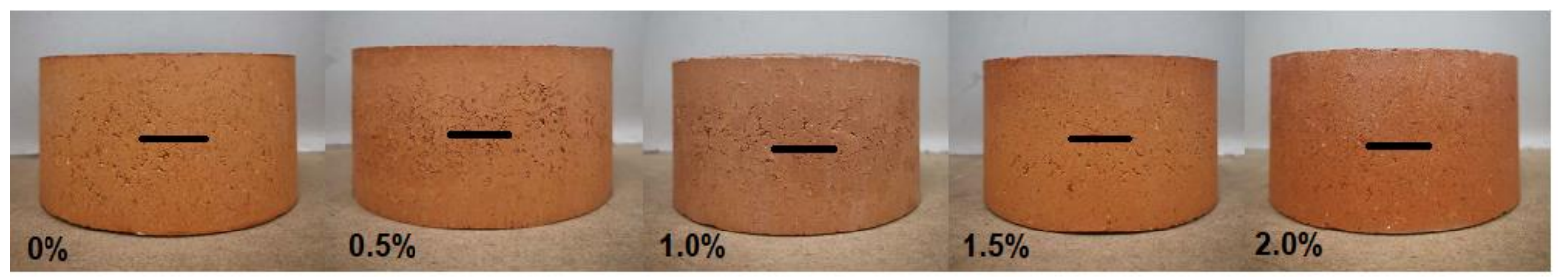

Figure 14. Efflorescence on bricks for mixes with $0 \%, 0.5 \%, 1.0 \%, 1.5 \%$, and $2.0 \%$ CBs. 
Figure 15 shows the X-ray computed tomography (CT) images of the $0 \%$ and $1 \%$ CB content bricks. The white pixels represent the open pores while the black pixels represent the material itself. The increase in CB content resulted in the development of pores of a greater number and size.
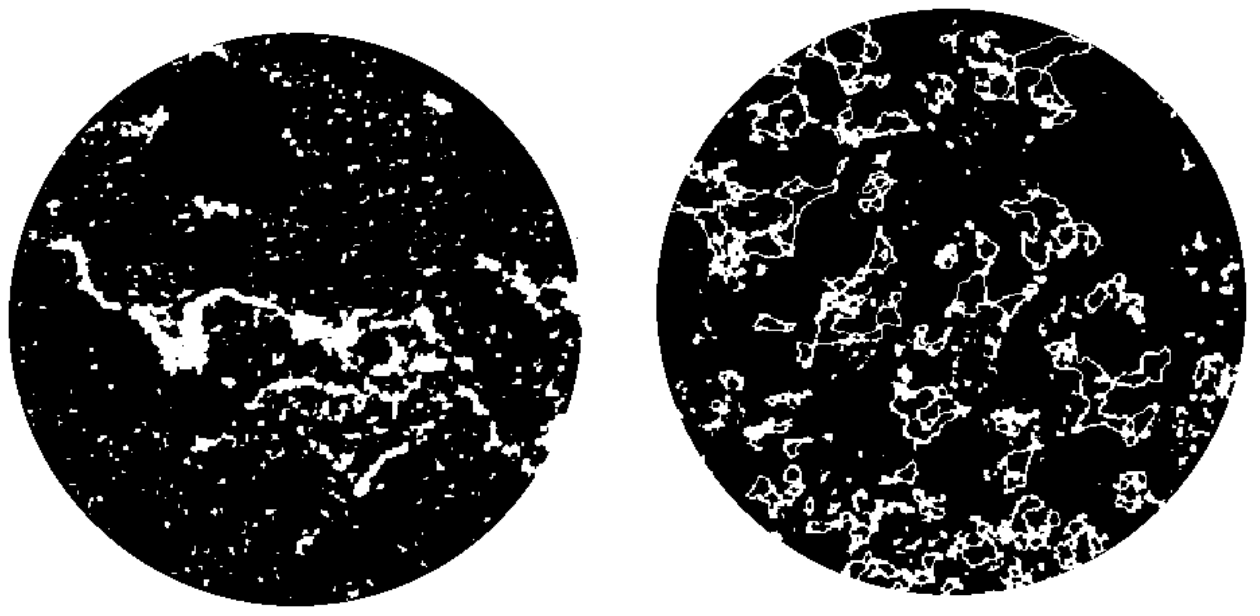

Figure 15. X-ray CT images of $0 \%$ (left) and $1 \%$ (right) $\mathrm{CB}$ content clay bricks.

\subsection{Energy Savings}

Using Equation (4), the estimated amounts of energy saved during the firing process of $0.5 \%, 1 \%$, $1.5 \%$, and $2 \%$ CBs by mass bricks were calculated and are given in Table 2 and Figure 16. The results show that, by firing bricks with $1 \%$ CBs by mass, there could be a possible $10.20 \%$ energy saving when compared to the control bricks. Furthermore, a 14.71\% energy saving can be achieved with an increase in the CB content ( $2 \%$ CB bricks). This is due to the waste having a higher heating value, which is added through self-combustion within the clay mixture during the firing process [9].

Table 2. Calculated value of energy saved during the firing of brick samples.

\begin{tabular}{|c|c|c|c|c|c|c|c|c|c|}
\hline $\begin{array}{c}\text { Mixture } \\
\text { Identification } \\
\%\end{array}$ & $\begin{array}{c}\text { Mass of } \\
\text { Clay } \\
\text { Brick, } \\
\text { m }_{1} \\
\text { Kg }\end{array}$ & $\begin{array}{c}\text { Mass of } \\
\text { Clay-CB } \\
\text { Brick } \\
\mathbf{m}_{2} \\
\text { Kg }\end{array}$ & $\begin{array}{c}\text { Mass of } \\
\text { CBs in } \\
\text { Clay-CB } \\
\text { Brick } \\
\mathrm{m}_{3} \\
\mathrm{Kg}\end{array}$ & $\begin{array}{c}\text { Energy } \\
\text { Used for } \\
\text { Brick } \\
\text { Firing } \\
\text { q } \\
\mathrm{MJ} / \mathrm{kg}\end{array}$ & $\begin{array}{c}\text { Calorific } \\
\text { Value } \\
\text { CV } \\
\mathrm{MJ} / \mathrm{kg}\end{array}$ & $\begin{array}{c}\text { Energy } \\
\text { Used for } \\
\text { Control } \\
\text { Brick } \\
Q_{1} \\
\text { MJ }\end{array}$ & $\begin{array}{c}\text { Energy } \\
\text { Used for } \\
\text { Clay-CB } \\
\text { Brick } \\
\mathrm{Q}_{2} \\
\mathrm{MJ}\end{array}$ & $\begin{array}{c}\text { Energy } \\
\text { Saved } \\
\mathbf{Q}_{1}-\mathbf{Q}_{2} \\
\mathbf{M J}\end{array}$ & $\begin{array}{c}\text { Percentage of } \\
\text { Energy Saved } \\
\left(\mathbf{Q}_{1}-\mathbf{Q}_{2}\right) / Q_{1} \times \\
\mathbf{1 0 0} \\
\%\end{array}$ \\
\hline CB (0.5) & 0.758 & 0.749 & 0.004 & 2 & 16.53 & 1.52 & 1.44 & 0.080 & 5.27 \\
\hline $\mathrm{CB}(2.0)$ & 0.758 & 0.738 & 0.011 & 2 & 16.53 & 1.52 & 1.29 & 0.223 & 14.71 \\
\hline
\end{tabular}

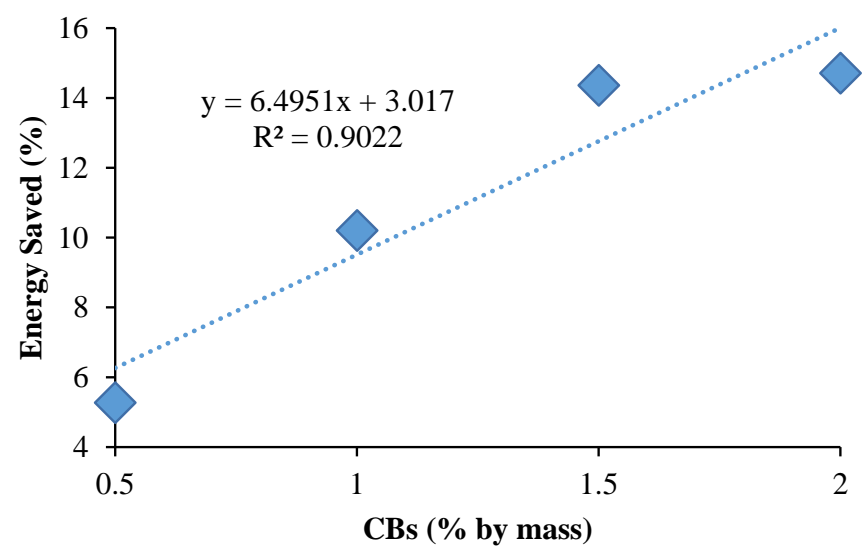

Figure 16. Energy saving versus CB percentage by mass. 


\subsection{Thermal Conductivity}

Using Equation (5), the estimated thermal conductivities for five different brick samples were calculated, and are given in Table 3 and Figure 17. As shown, the increase in CB content results in a reduction in density and thermal conductivity. The incorporation of $1 \%$ CBs reduces thermal conductivity by $17 \%$. Lower thermal conductivity is beneficial, as it will decrease the energy consumed for cooling and heating.

Table 3. Thermal conductivity of all estimated samples.

\begin{tabular}{cccc}
\hline $\begin{array}{c}\text { Mixture } \\
\text { Identification } \\
\mathbf{\%}\end{array}$ & $\begin{array}{c}\text { Dry Density } \\
\mathbf{k g} / \mathbf{m}^{3}\end{array}$ & $\begin{array}{c}\text { Thermal } \\
\text { Conductivity } \\
\mathbf{W} / \mathbf{m K}\end{array}$ & $\begin{array}{c}\text { Reduction of Thermal } \\
\text { Conductivity } \\
\mathbf{\%}\end{array}$ \\
\hline $\mathrm{CB}(0)$ & 2114 & 1.078 & 0 \\
$\mathrm{CB}(0.5)$ & 2026 & 0.953 & $11.66 \%$ \\
$\mathrm{CB}(1.0)$ & 1983 & 0.898 & $16.76 \%$ \\
$\mathrm{CB}(1.5)$ & 1972 & 0.884 & $18.06 \%$ \\
$\mathrm{CB}(2.0)$ & 1969 & 0.880 & $18.35 \%$ \\
\hline
\end{tabular}

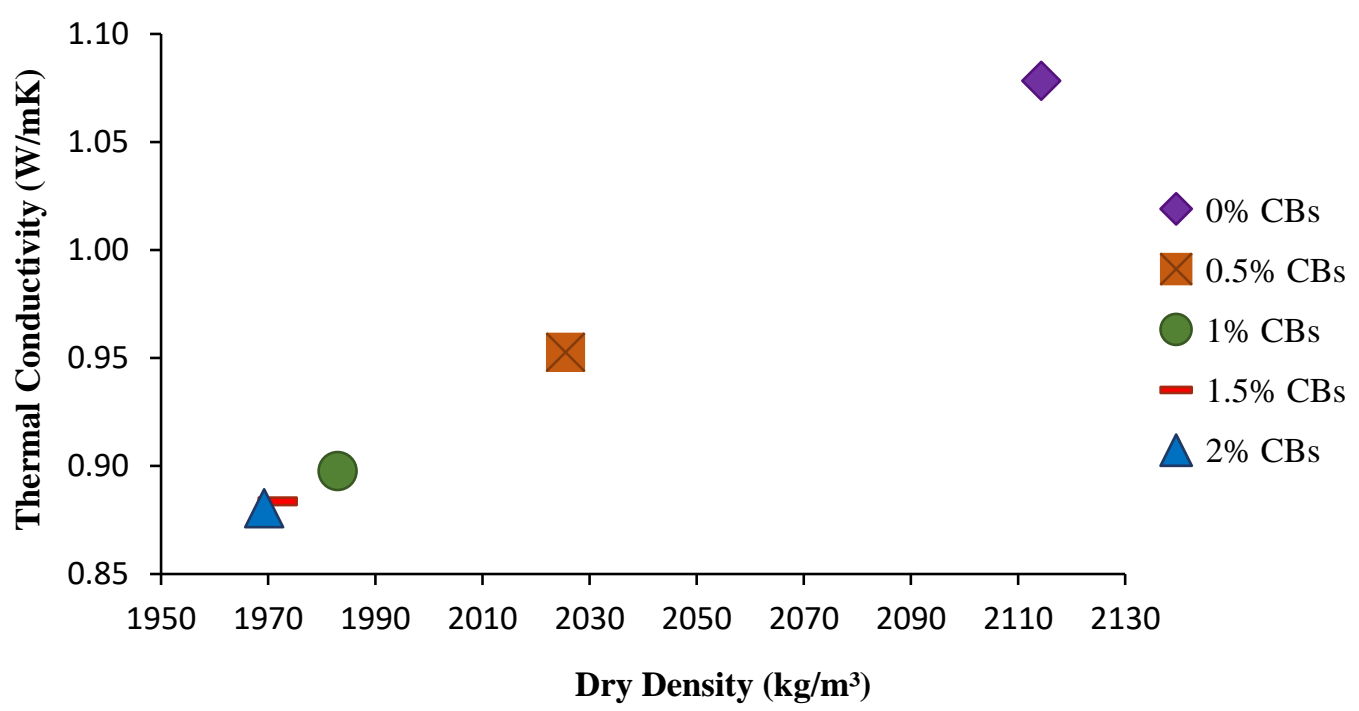

Figure 17. Thermal conductivity of each brick sample.

Based on the new energy transfer, Equation (9), the energy savings between a fired clay brick wall with $0 \%$ CB content and a fired clay brick wall with $0.5 \%, 1 \%, 1.5 \%$, and $2 \%$ CB content was calculated (Table 4). For the purpose of this example, a 3-m high and 3-m wide wall was considered over a period of 1 year (Figure 18). The thermal conductivity values are taken from Table 3. The temperature of the inner and outer surfaces of the wall is assumed to be $283.15 \mathrm{k}$ and $273.15 \mathrm{k}$, respectively. Heat flows from the warmer object to the cooler object until they are at the same temperature. The depth of the brick is taken as $0.1 \mathrm{~m}$, and it is assumed that the heat transfer through the wall is steady and that thermal conductivity is constant. 
Table 4. Energy savings between a fired clay brick wall with $0 \% \mathrm{CB}$ content and $0.5 \%, 1 \%, 1.5 \%$, and $2 \%$ CB content.

\begin{tabular}{|c|c|c|c|c|c|c|c|}
\hline $\begin{array}{c}\text { Mixture } \\
\text { Identification } \\
\%\end{array}$ & $\begin{array}{c}\text { Thermal } \\
\text { Conductivity } \\
\mathbf{k} \\
\mathrm{W} / \mathrm{mK}\end{array}$ & $\begin{array}{c}\text { Area of } \\
\text { Wall } \\
\text { A } \\
\mathbf{m}^{2}\end{array}$ & $\begin{array}{c}\text { Change in } \\
\text { Temperature } \\
\Delta \mathrm{T}=\mathrm{T}_{\text {hot }}-\mathrm{T}_{\text {cold }} \\
\text { kelvin }\end{array}$ & $\begin{array}{c}\text { Time } \\
\mathbf{t} \\
\mathrm{h}\end{array}$ & $\begin{array}{c}\text { Thickness } \\
\text { of Brick } \\
\text { L } \\
\text { m }\end{array}$ & $\begin{array}{c}\text { Energy } \\
\text { Transfer } \\
\text { Q } \\
\text { kwh }\end{array}$ & $\begin{array}{c}\text { Energy } \\
\text { Saved } \\
\%\end{array}$ \\
\hline $\mathrm{CB}(0)$ & 1.078 & 9 & 10 & 8760 & 0.1 & 8.50 & - \\
\hline CB (0.5) & 0.953 & 9 & 10 & 8760 & 0.1 & 7.51 & $11.60 \%$ \\
\hline CB (1.0) & 0.898 & 9 & 10 & 8760 & 0.1 & 7.08 & $16.70 \%$ \\
\hline CB (1.5) & 0.884 & 9 & 10 & 8760 & 0.1 & 6.97 & $18.00 \%$ \\
\hline CB (2.0) & 0.880 & 9 & 10 & 8760 & 0.1 & 6.94 & $18.37 \%$ \\
\hline
\end{tabular}

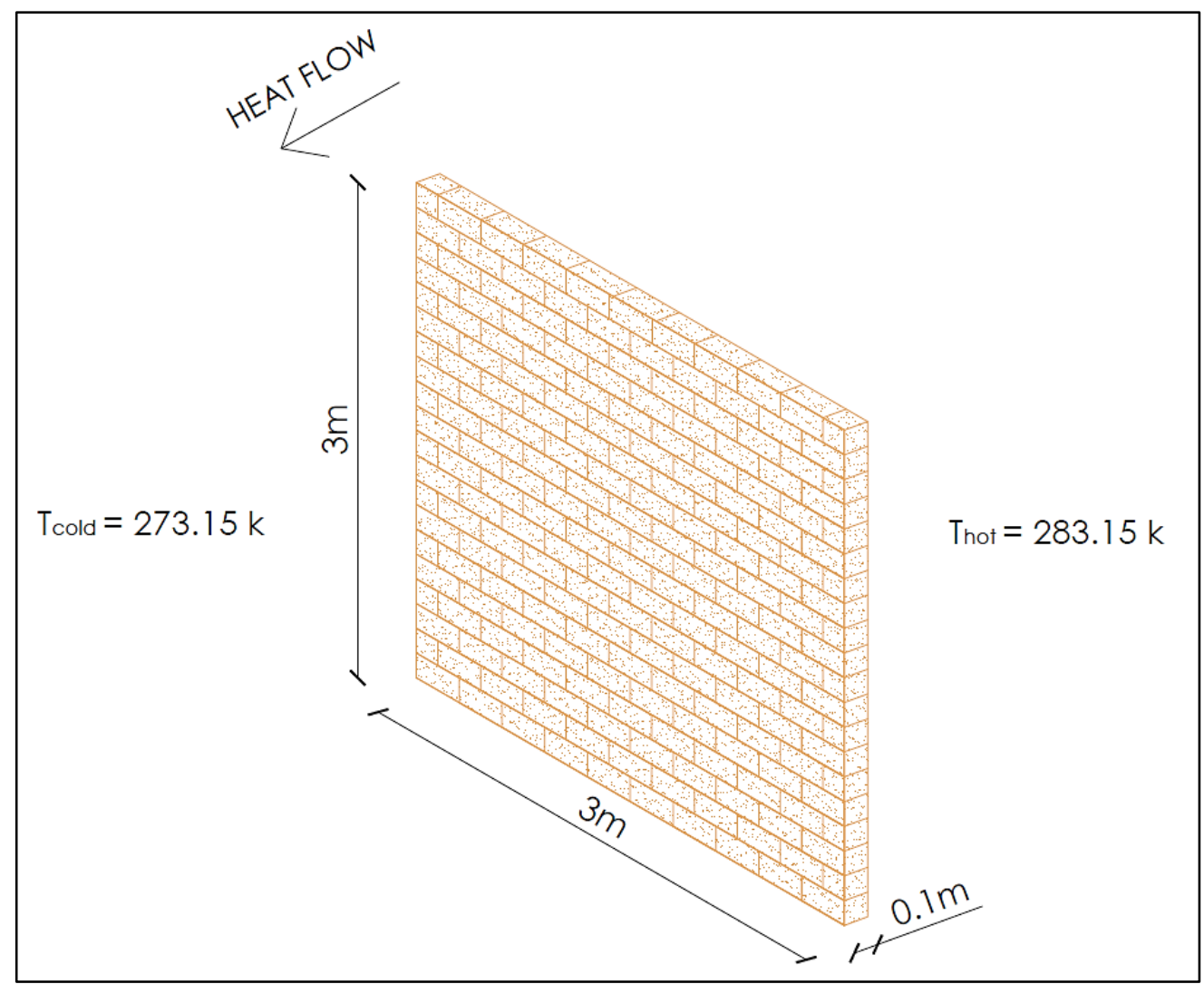

Figure 18. Fired clay brick wall.

In Table 4 it can be seen that the increase in CB content corresponds to the reduction in thermal conductivity, and, consequently, a reduction in the energy transfer between the fired clay brick walls. An energy savings of $16.7 \%$ was achieved for a brick wall with $1 \%$ CB content compared to a $0 \% \mathrm{CB}$ content wall. This reduction in energy transfer, and, therefore, the energy savings will decrease the costs of heating and cooling. A life-cycle assessment (LCA) is recommended to analyze the environmental impacts of fired clay bricks by incorporating CBs [58].

\section{Conclusions}

This study investigated the properties of $0.5 \%, 1 \%, 1.5 \%$, and $2 \%$ CB bricks by mass and compared them with those of standard fired clay bricks. Numerous tests were conducted, including water absorption, efflorescence, initial rate of absorption (IRA), density, shrinkage, microstructural analyses, thermal conductivity, and energy savings based on the Australian Standards.

The compressive strength of the bricks tested decreased from $48.6 \mathrm{MPa}$ for $0 \% \mathrm{CB}$ content to $30.8 \mathrm{MPa}$ for $1 \% \mathrm{CB}$ mass. The lowest compressive strength value was obtained for the $2 \% \mathrm{CB}$ content 
bricks (27.2 MPa). The minimum recommended compressive strength is $3-5 \mathrm{MPa}$, and $5-10 \mathrm{MPa}$ for non-load and load-bearing fired clay bricks, respectively.

However, the dry density decreased with the increase in CB content from $2114 \mathrm{~kg} / \mathrm{m}^{3}$ for control bricks to $1983 \mathrm{~kg} / \mathrm{m}^{3}$ and $1969 \mathrm{~kg} / \mathrm{m}^{3}$ for $1 \%$ and $2 \%$ CB content bricks, which produces light-weight bricks. The advantages of light-weight construction material are cheaper to produce and have a lower overall life cycle energy usage and design flexibility. The diametric shrinkage values obtained were $4.64 \%$ and $3.45 \%$ for the $0 \%$ and $1 \%$ CBs by mass bricks, respectively, which rises fairly linearly as the CB content increased.

The highest value of water absorption occurred for the $2 \%$ CB content bricks, which reached an absorption rate of $13.1 \%$ compared to $9 \%$ for the control bricks. The initial rate of absorption was found to be $0.67 \mathrm{~kg} \mathrm{~m}^{-2} \mathrm{~min}^{-1}$ for $1 \%$ CBs by mass bricks and $0.44 \mathrm{~kg} \mathrm{~m}^{-2} \mathrm{~min}^{-1}$ for the control bricks. The increase in $\mathrm{CB}$ content resulted in the increase in pores both in size and occurrence, which increased the water absorption rate of the bricks.

The thermal conductivity was estimated by using a prediction model. The estimations showed that an increase in CB content could result in a significant decrease in the thermal conductivity, and, consequently, result in lower energy costs for cooling and heating.

The estimated amounts of energy saved during the firing process of $0.5 \%, 1.5 \%, 1 \% \mathrm{CB}$, and $2 \%$ CB content bricks were found using calculations. Approximate savings of $10.20 \%$ and $14.71 \%$ were seen for $1 \%$ and $2 \%$ CB content bricks, respectively.

Consequently, bricks incorporating CBs have the potential to provide substantial energy savings and a unique, sustainable recycling solution to a growing global waste catastrophe. However, it is essential to adhere to international regulations and standards regarding the handling and recycling of toxic waste materials.

The results found in this study complete and confirm the previous findings on recycling CBs in fired clay bricks at RMIT University and the published proposal that all CBs can be sustainably recycled in fired clay bricks by incorporating $1 \%$ CBs in $2.5 \%$ of the world's brick production [27].

Author Contributions: Supervision: A.M.; Methodology: H.K. and A.M.; Experimental Design: H.K. and A.M.; Laboratory Investigation: H.K.: Writing: H.K.; Editing and Reviewing: A.M. All authors have read and agreed to the published version of the manuscript.

Funding: This research received no external funding.

Acknowledgments: This work is part of an ongoing postgraduate study on recycling cigarette butts in construction materials. The authors would like to thank Butt-Out Australia Pty Ltd and RMIT University for their financial and in-kind support.

Conflicts of Interest: The authors declare no conflict of interest.

\section{References}

1. Munir, M.J.; Kazmi, S.M.S.; Wu, Y.-F.; Hanif, A.; Khan, M.U.A. Thermally efficient fired clay bricks incorporating waste marble sludge: An industrial-scale study. J. Clean. Prod. 2018, 174, 1122-1135. [CrossRef]

2. Raut, S.; Ralegaonkar, R.; Mandavgane, S. Development of sustainable construction material using industrial and agricultural solid waste: A review of waste-create bricks. Constr. Build. Mater. 2011, 25, 4037-4042. [CrossRef]

3. Sutcu, M. Influence of expanded vermiculite on physical properties and thermal conductivity of clay bricks. Ceram. Int. 2015, 41, 2819-2827. [CrossRef]

4. Sutcu, M.; Akkurt, S. The use of recycled paper processing residues in making porous brick with reduced thermal conductivity. Ceram. Int. 2009, 35, 2625-2631. [CrossRef]

5. Kazmi, S.M.S.; Munir, M.J.; Patnaikuni, I.; Wu, Y.-F.; Fawad, U. Thermal performance enhancement of eco-friendly bricks incorporating agro-wastes. Energy Build. 2018, 158, 1117-1129. [CrossRef]

6. Kadir, A.A. An overview of wastes recycling in fired clay bricks, International. J. Integr. Eng. 2012, 4, 53-69.

7. Erker, A. Thermal Conductivity of the Brick Ceramic Body (Part 1). ZI Int. 2002, 55, 34-42. 
8. Galal, A.; El-Wahed, A. Effect of mineralogical composition of shale/clay on the physical properties of structural bricks. Sprechsaal 1985, 118, 621-624.

9. Gualtieri, M.L.; Gualtieri, A.F.; Gagliardi, S.; Ruffini, P.; Ferrari, R.; Hanuskova, M. Thermal conductivity of fired clays: Effects of mineralogical and physical properties of the raw materials. Appl. Clay Sci. 2010, 49, 269-275. [CrossRef]

10. Velasco, P.M.; Ortíz, M.M.; Giró, M.M.; Velasco, L.M. Fired clay bricks manufactured by adding wastes as sustainable construction material - A review. Constr. Build. Mater. 2014, 63, 97-107. [CrossRef]

11. Bories, C.; Borredon, M.-E.; Vedrenne, E.; Vilarem, G. Development of eco-friendly porous fired clay bricks using pore-forming agents: A review. J. Environ. Manag. 2014, 143, 186-196. [CrossRef] [PubMed]

12. Folaranmi, J. Effect of additives on the thermal conductivity of clay. Leonardo J. Sci. 2009, 14, 74-77.

13. Dondi, M.; Mazzanti, F.; Principi, P.; Raimondo, M.; Zanarini, G. Thermal Conductivity of Clay Bricks. J. Mater. Civ. Eng. 2004, 16, 8-14. [CrossRef]

14. Erker, A. Thermal Conductivity of the Brick Ceramic Body (Part 2). ZI Int. 2002, 55, 32-37.

15. Bánhidi, V.; Gömze, L.A. Improvement of Insulation Properties of Conventional Brick Products, in Materials Science Forum; Trans Tech Publ.: Miskolc, Hungary, 2008; pp. 1-6.

16. Mastali, M.; Shaad, K.M.; Abdollahnejad, Z.; Falah, M.; Kinnunen, P.; Illikainen, M. Towards sustainable bricks made with fiber-reinforced alkali-activated desulfurization slag mortars incorporating carbonated basic oxygen furnace aggregates. Constr. Build. Mater. 2020, 232, 117258. [CrossRef]

17. Bilgin, N.; Yeprem, H.; Arslan, S.; Bilgin, A.; Günay, E.; Marşoglu, M. Use of waste marble powder in brick industry. Constr. Build. Mater. 2012, 29, 449-457. [CrossRef]

18. Pérez-Villarejo, L.; Eliche-Quesada, D.; Iglesias-Godino, F.J.; Martinez-García, C.; Corpas-Iglesias, F.A. Recycling of ash from biomass incinerator in clay matrix to produce ceramic bricks. J. Environ. Manag. 2012, 95, S349-S354. [CrossRef]

19. Sakhare, V.V.; Ralegaonkar, R.V. Use of bio-briquette ash for the development of bricks. J. Clean. Prod. 2016, 112, 684-689. [CrossRef]

20. Kazmi, S.M.S.; Munir, M.J.; Wu, Y.-F.; Hanif, A.; Patnaikuni, I. Thermal performance evaluation of eco-friendly bricks incorporating waste glass sludge. J. Clean. Prod. 2018, 172, 1867-1880. [CrossRef]

21. Aeslina, A.K.; Mohajerani, A. Leachability of heavy metals from fired clay bricks incorporated with cigarette butts. In Proceedings of the 2012 IEEE Symposium on Business, Engineering and Industrial Applications, Bandung, Indonesia, 23-26 September 2012; pp. 872-877.

22. Kadir, A.A.; Mohajerani, A. Recycling cigarette butts in lightweight fired clay bricks. Constr. Mater. 2011, 164, 219-229. [CrossRef]

23. Kadir, A.A.; Mohajerani, A. Possible utilization of cigarette butts in light-weight fired clay bricks. Int. J. Civ. Environ. Eng. 2008, 2, 137-141.

24. Kadir, A.A.; Mohajerani, A. Effect of heating rate on gas emissions and properties of fired clay bricks and fired clay bricks incorporated with cigarette butts. Appl. Clay Sci. 2015, 104, 269-276. [CrossRef]

25. Kadir, A.A.; Mohajerani, A. Bricks: An Excellent Building Material for Recycling Wastes-A Review. Environ. Manag. Eng. Unconv. Oil 2011. [CrossRef]

26. Kadir, A.A. Density, strength, thermal conductivity and leachate characteristics of light-weight fired clay bricks incorporating cigarette butts. Mater. Sci. 2009, 3, 242-247.

27. Mohajerani, A.; Kadir, A.A.; Larobina, L. A practical proposal for solving the world's cigarette butt problem: Recycling in fired clay bricks. Waste Manag. 2016, 52, 228-244. [CrossRef]

28. Eliche-Quesada, D.; Leite-Costa, J. Use of bottom ash from olive pomace combustion in the production of eco-friendly fired clay bricks. Waste Manag. 2016, 48, 323-333. [CrossRef]

29. La Rubia-García, M.D.; Yebra-Rodríguez, A.; Eliche-Quesada, D.; Corpas-Iglesias, F.A.; López-Galindo, A.; La Rubia, M.D. Assessment of olive mill solid residue (pomace) as an additive in lightweight brick production. Constr. Build. Mater. 2012, 36, 495-500. [CrossRef]

30. Eriksen, M.P.; Mackay, J.; Ross, H. The Tobacco Atlas; American Cancer Society: New York, NY, USA, 2012; Available online: https://tobaccoatlas.org/topic/consumption/ (accessed on 18 January 2020).

31. Puls, J.; Wilson, S.A.; Hölter, D. Degradation of cellulose acetate-based materials: A review. J. Polym. Environ. 2011, 19, 152-165. [CrossRef]

32. Wallbank, L.A.; MacKenzie, R.; Beggs, P.J. Environmental impacts of tobacco product waste: International and Australian policy responses. Ambio 2017, 46, 361-370. [CrossRef] 
33. Clean Up Australia. Clean Up Australia Rubbish Report; Issuu: Darlinghurst, Australia, 2017; Available online: https://www.cleanup.org.au/rubbish-report (accessed on 1 August 2018).

34. Hoffmann, D.; Hoffmann, I.; El-Bayoumy, K. The less harmful cigarette: A controversial issue. a tribute to Ernst L. Wynder. Chem. Res. Toxicol. 2001, 14, 767-790. [CrossRef]

35. Martin, T. Cigarette Tar and How It Can Hurt You; Verywell Mind: New York, NY, USA, 2018; Available online: https://www.verywellmind.com/tar-in-cigarettes-2824718 (accessed on 1 April 2018).

36. Hoffmann, D.; Djordjevic, M.V.; Brunnemann, K.D. Changes in cigarette design and composition over time and how they influence the yields of smoke constituents. J. Smok. Relat Disord 1995, 6, 9-23.

37. Ach, A. Biodegradable Plastics Based on Cellulose Acetate. J. Macromol. Sci. Part A 1993, 30, 733-740. [CrossRef]

38. Hon, N.-S. Photodegradation of cellulose acetate fibers. J. Polym. Sci. Polym. Chem. Ed. 1977, 15, 725-744. [CrossRef]

39. Kurmus, H.; Mohajerani, A. The toxicity and valorization options of cigarette butts. Waste Manag. 2020, 104, 104-118. [CrossRef]

40. Yuan, Y.; Lu, Z.; Huang, L.; Bie, X.; Lü, F.; Li, Y. Optimization of a medium for enhancing nicotine biodegradation by Ochrobactrum intermedium DN2. J. Appl. Microbiol. 2006, 101, 691-697. [CrossRef]

41. Knox, A. An Overview of Incineration and EFW Technology as Applied to the Management of Municipal Solid Waste (MSW), ONEIA Energy Subcommitte, University of Western Ontario. 2005. Available online: http://www. durhamenvironmentwatch.org/Incinerator\%20Files\%20II/OverviewOfIncinerationAndEFWKnox.pdf (accessed on 3 December 2019).

42. Standards Australia. Methods for Testing Soils for Engineering Purposes. Soil Classification Tests-Determination of the Particle size Distribution of a Soil—Standard Method of Analysis by Sieving (AS1289.3.6.1); SAI Global Limited: Sydney, Australia, 2009.

43. Standards Australia. Methods for Testing Soils for Engineering Purposes. Soil Classification Tests_Determination of the Plastic Limit of a soil-Standard Method (AS1289.3.2.1); SAI Global Limited: Sydney, Australia, 2009.

44. Standards Australia. Methods of Testing Soils for Engineering Purposes. Soil Classification Tests-Determination of the Liquid Limit of a Soil-Four Point Casagrande Method (AS1289.3.1.1); SAI Global Limited: Sydney, Australia, 2009.

45. Standards Australia. Masonary Units and Segmental Pavers and Flags-Methods of Test-Sampling for Test (AS1289.5.5.1); SAI Global Limited: Sydney, Australia, 2003.

46. Prasertsan, S. Preliminary Study on Brick Making Industry in ASEAN Countries, Final Report; NRCT: Bangkok, Thailand, 1995.

47. Bouchair, A. Steady state theoretical model of fired clay hollow bricks for enhanced external wall thermal insulation. Build. Environ. 2008, 43, 1603-1618. [CrossRef]

48. Kingery, W.D. Thermal Conductivity: XIV, Conductivity of Multicomponent Systems. J. Am. Ceram. Soc. 1959, 42, 617-627. [CrossRef]

49. Standards Australia. Pavers, Flags and Segmental Retaining Wall Units-Masonry Units (AS/NZS 4455.1); SAI Global Limited: Sydney, Australia, 2008.

50. Electronic Blueprint. The Premier Building Specification, Detailing and Training Reference. Available online: http://www.electronicblueprint.com.au/specifications/12-MASONRY.doc (accessed on 4 March 2019).

51. Arnold, W.; Davies, S.; Sinha, G.; Sinha, B. Design of Masonry Structures; Taylor \& Francis: London, UK, 2004.

52. Mastali, M.; Abdollahnejad, Z.; Pacheco-Torgal, F. Carbon dioxide sequestration of fly ash alkaline-based mortars containing recycled aggregates and reinforced by hemp fibres. Constr. Build. Mater. 2018, 160, 48-56. [CrossRef]

53. Kayali, O. Published. High performance bricks from fly ash. In Proceedings of the World of Coal Ash Conference, Lexington, KY, USA, 11-15 April 2005; University of Kentucky Center for Applied Energy Research and the American Coal Fly Ash Association: Lexington, KY, USA, 2005.

54. Ukwatta, A.; Mohajerani, A.; Eshtiaghi, N.; Setunge, S. Variation in physical and mechanical properties of fired-clay bricks incorporating ETP biosolids. J. Clean. Prod. 2016, 119, 76-85. [CrossRef]

55. Phonphuak, N.; Kanyakam, S.; Chindaprasirt, P. Utilization of waste glass to enhance physical-mechanical properties of fired clay brick. J. Clean. Prod. 2016, 112, 3057-3062. [CrossRef]

56. Baspinar, M.S.; Demir, I.; Orhan, M. Utilization potential of silica fume in fired clay bricks. Waste Manag. Res. 2010, 28, 149-157. [CrossRef] [PubMed] 
57. Standards Australia. Masonry Units and Segmental Pavers and Flags. Methods of Test-Determining Potential to Effloresce (AS4456.6); SAI Global Limited: Sydney, Australia, 2003.

58. Mohajerani, A.; Ukwatta, A.; Setunge, S. Fired-Clay Bricks Incorporating Biosolids: Comparative Life-Cycle Assessment. J. Mater. Civ. Eng. 2018, 30, 04018125. [CrossRef]

(C) 2020 by the authors. Licensee MDPI, Basel, Switzerland. This article is an open access article distributed under the terms and conditions of the Creative Commons Attribution (CC BY) license (http://creativecommons.org/licenses/by/4.0/). 